\title{
Lipopolysaccharide-Induced Memory Impairment in Rats: a Model of Alzheimer's Disease
}

\author{
R. ZAKARIA ${ }^{1}$, W. M. H. WAN YAACOB ${ }^{2}$, Z. OTHMAN ${ }^{3}$, I. LONG ${ }^{2}$, A. H. AHMAD ${ }^{1}$, \\ B. AL-RAHBI ${ }^{4}$
}

${ }^{1}$ Department of Physiology, School of Medical Sciences, Universiti Sains Malaysia, Kubang Kerian, Malaysia, ${ }^{2}$ School of Health Sciences, Universiti Sains Malaysia, Kubang Kerian, Malaysia, ${ }^{3}$ Department of Psychiatry, School of Medical Sciences, Universiti Sains Malaysia, Kubang Kerian, Malaysia, ${ }^{4}$ Institute of Health Sciences, Ministry of Health, Muscat, Oman

Received September 5, 2016

Accepted January 6, 2017

On-line April 12, 2017

\begin{abstract}
Summary
Alzheimer's disease (AD) is a primary cause of dementia in the middle-aged and elderly worldwide. Animal models for AD are widely used to study the disease mechanisms as well as to test potential therapeutic agents for disease modification. Among the non-genetically manipulated neuroinflammation models for $A D$, lipopolysaccharide (LPS)-induced animal model is commonly used. This review paper aims to discuss the possible factors that influence rats' response following LPS injection. Factors such as dose of LPS, route of administration, nature and duration of exposure as well as age and gender of animal used should be taken into account when designing a study using LPS-induced memory impairment as model for AD.
\end{abstract}

\section{Key words}

Alzheimer's disease • Lipopolysaccharide • Rats • Memory impairment

\section{Corresponding author}

Z. Othman, Department of Psychiatry, School of Medical Sciences, Universiti Sains Malaysia, 16150 Kubang Kerian, Malaysia. E-mail: zahirkb@usm.my

\section{Introduction}

Alzheimer's disease (AD) was first described by Alois Alzheimer in 1906. It is a progressive neuropsychiatric disorder characterized by progressive loss of cognitive abilities (Wilkins and Brody 1969, Cavanaugh et al. 2014). It is a debilitating, ultimately fatal disease and is the primary cause of dementia in the middle-aged and elderly (Wilkins and Brody 1969, Fitzpatrick et al. 2005, Alzheimer's Disease International 2009, Cavanaugh et al. 2014).

The common initial symptoms are forgetfulness and difficulties with routine tasks. As the disease progresses, patients develop more severe memory loss, speech impairment, visual and spatial deficits, and loss of coordination and fine motor control (Rossor et al. 1996, Alzheimer's Disease International 2009, Obermeyer et al. 2012). Besides the cognitive, sensory, and motor deficits caused by the disease progression, there are a number of behavioral and psychological symptoms related to dementia. These symptoms include agitation and aggression, wandering, disturbances in the sleep cycle, depression, anxiety, delusions and hallucinations (Ferri et al. 2004, de Vugt et al. 2005, Obermeyer et al. 2012). $\mathrm{AD}$ reduces the life expectancy of those affected, with an average survival time after diagnosis of 5-7 years (Fitzpatrick et al. 2005, Ganguli et al. 2005).

$\mathrm{AD}$ can be categorized into early and late onset. Early-onset $\mathrm{AD}$ (EOAD) typically begins between the ages of 30 and 60 years, and accounts for fewer than $5 \%$ of $\mathrm{AD}$ cases. The more common form, late-onset or sporadic $\mathrm{AD}$ (LOAD), presents after the age of 65 (Rossor et al. 1996, Irvine et al. 2008). 


\section{Risk factors for Alzheimer's Disease}

The single greatest risk factor for developing $\mathrm{AD}$ is age, with a risk of $10 \%$ for persons older than 65 years and nearly $50 \%$ for those older than 85 years (Rossor et al. 1996, Gatz et al. 2006, Chai 2007).

Apart from age, genetic component is another risk factor for $\mathrm{AD}$. Autosomal dominant familial $\mathrm{AD}$ (FAD), which is typically an EOAD, has been linked to mutations in genes encoding presenilin1 (PSEN1), presenilin2 (PSEN2), and beta-amyloid precursor protein (APP) (Chartier-Harlin et al. 1991, Goate et al. 1991, Mullan et al. 1992, Schellenberg et al. 1992, Levy-Lahad et al. 1995, Sherrington et al. 1995). Inheritance of the apolipoprotein E type 4 allele (ApoE4) may also increase the risk of developing sporadic LOAD, though ApoE4 alone is neither necessary nor sufficient to cause $\mathrm{AD}$ (Corder et al. 1993, Strittmatter et al. 1993, Rossor et al. 1996, Sadigh-Eteghad et al. 2012).

\section{Non-genetically manipulated neuro-inflammation models for AD}

The unique neuropathological hallmarks of $\mathrm{AD}$ are extracellular accumulation of beta-amyloid $(\mathrm{A} \beta)$ peptide and intracellular accumulation of hyperphosphorylated tau protein or neurofibrillary tangles (NFTs,) (Hardy and Selkoe 2002, Iqbal and GrundkeIqbal 2006). A true model that fits the inflammation hypothesis of $\mathrm{AD}$ is an aged animal (older than 22 months) that manifests early chronic neuroinflammation lasting more than 7 days prior to hyperphosphorylation of tau and $\mathrm{A} \beta$ plaque deposition (Burton and Johnson 2012).

The intracellular accumulation of $A \beta$, especially A $\beta 1-42$, has been shown to precede the formation of extracellular amyloid deposits in subjects with $\mathrm{AD}$ and trisomy 21 (Gouras et al. 2000), in brains of young Tg mice (8-month-old) harboring APP with three FAD-linked mutations (KM670/671NL, E693Q, and V7171) and the PS1 mutation M146L (Wirths et al. 2001), and in the brains of older $\mathrm{Tg}$ mice (17-month-old) harboring various FAD-linked PS1 mutations (Chui et al. 1999). Based on these findings, Sheng et al. (2003) concluded that intracellular accumulation of $A \beta$ may be an early stage of a process that may eventually lead to extracellular amyloid deposits and the formation of plaques.
However, other potential rodent models of $\mathrm{AD}$ that present with early neuroinflammation in the disease process and are not genetically manipulated by mutations related to $A \beta$ or tau production are also commonly used. These include lipopolysaccharide (LPS)-, polyI C-, streptozotocin-, okadaic acid- and colchicine-induced neuroinflammation. LPS-induced neuroinflammation represents the current standard paradigm to study neuroinflammation both in vivo (Hauss-Wegrzyniak et al. 1998, Sheng et al. 2003, Anaeigoudari et al. 2016) and in vitro (Candiracci et al. 2012). There are several other non-genetically manipulated rat models of $\mathrm{AD}$ which are not limited to induced neuroinflammation. For example, the ferrous amyloid buthionine $(\mathrm{FAB})$ rat model (Lecanu and Papadopoulos 2013), the sodium azide model (Szabados et al. 2004) and the Samaritan AD rat model (Petrasek et al. 2016). This review focuses only on the widely studied LPS-induced cognitive deficit in rats and the possible factors that can influence rats' response to LPS.

\section{Lipopolysaccharide}

LPS is used worldwide in experimental in vitro and in vivo models of neuroinflammation and amyloidosis (Miklossy 2008). LPS-induced systemic inflammation is used in a number of neurodegenerative diseases; $\mathrm{AD}$ (Hauss-Wegrzyniak et al. 1998; Sheng et al. 2003; Anaeigoudari et al. 2016), Parkinson disease (Gao et al. 2002; Whitton 2007), amyotrophic lateral sclerosis (Zhao et al. 2004) and multiple sclerosis (Walter et al. 2006).

LPS is a component of the outer membrane of gram-negative bacteria. It is a potent endotoxin and is highly resistant to degradation by mammalian enzymes thus providing a persistent inflammatory stimulus (Ohanian and Schwab 1967) that produces proinflammatory cytokines. These proinflammatory cytokines activate both the neuroimmune and neuroendocrine systems (Maitra et al. 2012) that result in similar responses as produced by behavioral stress (Oitzl et al. 1993).

LPS produces a wide range of non-specific behavioral effects collectively termed 'sickness behaviors' (Klein and Nelson 1999). These behaviors include reduction in activity, reduction in exploration, decreased social interaction, fever, reduction in consumption of food and drink, hypersomnia, activation of the hypothalamic-pituitary-adrenal (HPA) axis and 
causing increased sympathetic activation (Hart 1988, Kebt et al. 1992, Pugh et al. 1998).

\section{Mechanism of action of LPS in the central nervous system (CNS)}

A direct action of LPS within the CNS is an important possibility (Elmquist et al. 1997). It is possible that LPS can access the brain directly via peripheral nerve transduction (Hansen et al. 2000), the circumventricular organs (Blatteirs et al. 1992), area postrema (Ericsson et al. 1994) or even at the level of the hypothalamus (Yasuda and Greer 1978, Zhang et al. 2000). Mechanism of LPS action in CNS is shown in Figure 1.

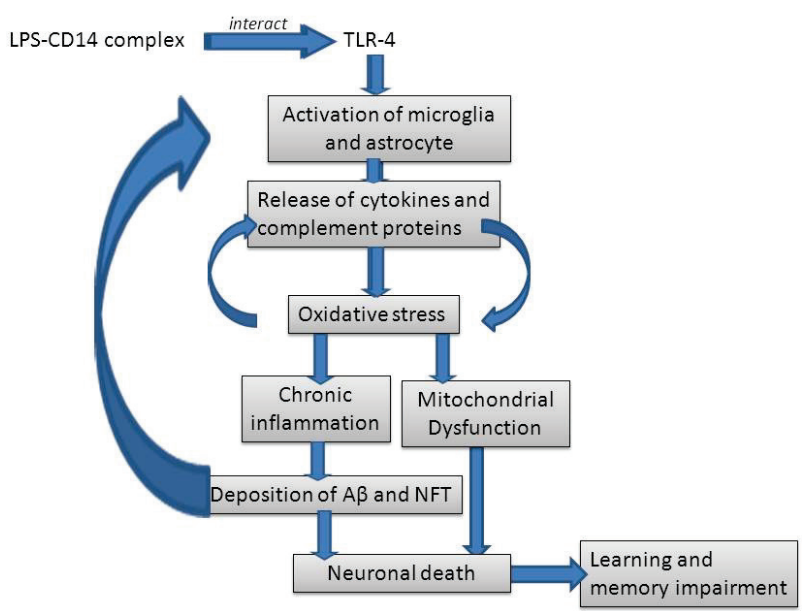

Fig. 1. Mechanism of LPS action in CNS.

LPS binds CD14 on microglia membranes forming the LPS-CD14 complex which then interacts with toll-like receptor (TLR)-4 (Hailman et al. 1994, Lehnardt et al. 2003). TLR-4, in turn, activates microglia by initiating signal transduction cascades leading to rapid transcription and release of proinflammatory cytokines including interleukin (IL)-1, IL-6, IL-12, IL-17A, IL-18, $\mathrm{p} 40$, inducible nitric oxide synthase (iNOS) and tumor necrosis factor- $\alpha$ (TNF- $\alpha$ ) (Rivest 2009, Bossu et al. 2012, Sun et al. 2015); chemokines such as CCL2, CCL5, and CXCL8; complement system proteins such as C3, C3a, and C5a receptors (Rivest 2009); and anti-inflammatory cytokines such as IL-10 (Mizuno et al. 1994) and transforming growth factor- $\beta$ (TGF- $\beta$ ) (Welser-Alves and Milner 2013). It has been shown that the level of expression of TNF- $\alpha$, IL- $1 \beta$, and IL- 6 in the hippocampus was increased compared to controls after three days of LPS administration (Daulatzai 2016).

Proinflammatory cytokines are key molecules that modulate immune responses. Their lack of reversibility in chronic inflammation would enhance dyshomeostasis (Ghosh et al. 2015). Chronic inflammation is characterized by long-standing activation of microglia that sustains the release of inflammatory mediators, leading to an increase of oxidative and nitrosative stress. This perpetuates the inflammatory cycle (Tansey et al. 2007), further prolonging the inflammation (Schmid et al. 2009) that is detrimental for several neurodegenerative diseases (Block and Hong 2005).

An excessive inflammatory response is characterized not only by elevated proinflammatory cytokines, but also by increases in mitochondrial dysfunction, reactive oxygen species (ROS), and nitric oxide (NO). Consequently, there may be damage to the systemic vascular endothelium, redox-glutathione depletion, and mitochondrial respiratory dysfunction causing reduction in ATP and $\mathrm{O}_{2}$ consumption. Hence, inflammation and oxidative stress are intertwined (Exline and Crouser 2008, Bivalacqua et al. 2009, Victor et al. 2009, Galley 2011, Lowes et al. 2013) and have been implicated in the pathophysiology of AD.

It has been shown that inflammatory cytokines such as IL-1 $\beta$, IL-6, TNF- $\alpha$ and TGF- $\beta$ can augment APP expression (Buxbaum et al. 1992, Hirose et al. 1994) and $\mathrm{A} \beta$ formation (Blasko et al. 1999). It has also been reported that cytokines are able to transcriptionally upregulate $\beta$-secretase mRNA, protein and enzymatic activity (Sastre et al. 2003). $\beta$-secretase is a key rate-limiting enzyme that initiates $A \beta$ formation (Vassar 2001). Without $\beta$-secretase, $A \beta$ synthesis is either abolished or considerably reduced (Walter et al. 2001).

It has been pointed out in the literature that LPS-induced inflammation promotes $\mathrm{AD}$ pathology by altering $\mathrm{A} \beta$ transport at the blood brain barrier (BBB) (Jaeger et al. 2009) and decreasing the central clearance of $\mathrm{A} \beta$ (Erickson et al. 2012). Alteration of BBB effectively increases brain influx of $A \beta$ but decreases its efflux (Jaeger et al. 2009). The level of expression of $A \beta$ in the hippocampus is shown to increase (compared with controls) after seven days of LPS administration (Daulatzai 2016).

LPS-induced neuronal cell death could be the result of cyclooxygenase-2 (COX-2) and extracellular signal-regulated kinase (ERK) activation (Lee et al. 
2008). COX-2 is barely detectable under normal physiological conditions, but can be induced rapidly and transiently by proinflammatory mediators and mitogenic stimuli, thereby mediating deleterious effects in the neurodegenerative disorders (Pasinetti et al. 2001). In Alzheimer brain, COX-2 is notably up-regulated, which seems to be associated with $\mathrm{A} \beta$ plaque formation (Pasinetti et al. 1998, Hoozemans et al. 2001, Pasinetti et al. 2002). Conversely, deposition of $A \beta$ in the brain has been reported to trigger an inflammatory response associated with the neuropathophysiology of AD (Paris et al. 2002). Jang and Surh (2005) showed that $A \beta$-induced apoptosis is associated with COX-2 up-regulation through activation of NF- $\mathrm{B}$, which is mediated by upstream kinases including ERK and p38 mitogenactivated protein kinases (MAPK).

LPS may disrupt the consolidation of certain memory processes. Acute administration of LPS prior to training impairs contextual-cue fear conditioning, a hippocampal-dependent learning paradigm (Pugh et al. 1998); while chronic infusion of LPS has been found to impair spatial memory (Hauss-Wegrzyniak et al. 1998, Hauss-Wegrzyniak et al. 2000) and induce memory and learning deficits analogous to $\mathrm{AD}$ cognitive decline (Lee et al. 2008). Systemic LPS administration leads to selective hippocampal impairment in context-object discrimination but not spatial memory (Czerniawski et al. 2015). Major cognitive findings in LPS-treated rats are summarized in Table 1.

\section{Animal response following LPS administration}

There are a number of factors that can influence animal response to LPS injections, including dose, nature of exposure, route of administration, duration of exposure, age and gender of the animals.

\section{Dose of LPS}

Houdek et al. (2014) demonstrated that direct LPS infusion into the fourth ventricle of the male rat brain resulted in a dose-dependent response of activated microglia and astrocyte. Very low-dose LPS infusion $(0.05 \mathrm{ng} / \mathrm{h})$ was sufficient to induce neuroglial activation while moderate and high doses ( $50 \mathrm{ng} / \mathrm{h}$ and above) were required to induce significant loss of choline acetyltransferase (ChAT)-positive cells in the basal forebrain.
Nature of LPS exposure

Pugh et al. (1998) demonstrated that 0.125 and $0.25 \mathrm{mg} / \mathrm{kg}$ LPS interfered with contextual fear conditioning, while $0.5 \mathrm{mg} / \mathrm{kg}$ had no effect. Similarly, LPS differentially affects the hypothalamic-pituitary axis in that a higher dose of LPS stimulates the sustained release of corticosterone (Nguyen et al. 1998, Pugh et al. 1998). This appears to be only true for acute exposure to LPS; repeated injections of LPS have no such effect on corticosterone levels (Takemura et al. 1997).

Later studies by Shaw et al. (2001) showed that a single injection of LPS impaired escape latency in both the acquisition and retention phases of the Morris water maze while a daily injection did not. Repeated LPS exposure also resulted in lower IL-1 $\beta$ activation; this may be due to an alteration in peripheral sympathetic responsiveness (Zhang et al. 2000). It is possible that repeated exposure to LPS produces a tolerance effect, as suggested by the lower IL-1 $\beta$ activation, which may account for the observed behavioral changes in the study.

Repeated endotoxin exposure has long been known to result in a tolerance-like phenomenon (Habicht 1981). The acute administration of LPS has been better characterized, and a few studies have examined the effects of repeated LPS injections upon behavior or how endotoxin tolerance may be observed in terms of an animal's learning. Kobayashi et al. (2002) demonstrated at least one of the molecular bases for the tolerance-like phenomenon. They showed that repeated stimulation of the TLR results in the induction of IL-1 receptor associated kinase-M (IRAK-M), negatively regulating the TLR signaling cascade by halting IRAK's interaction with TNF-receptor associated factor-6 (TRAF6). This mechanism of tolerance may be an adaptive event critical in avoiding endotoxic shock.

\section{Route of LPS administration}

The most common routes of LPS administration for LPS-induced cognitive impairment rat model are intraperitoneal and intracerebroventricular. However, we found no studies that explicitly compare different routes of LPS administration with the effect of cognitive function in rats.

\section{Duration of LPS exposure}

Bordou and colleagues (2014) investigated the role of duration of exposure to LPS on the neuroinflammatory response to LPS. Male rats received 
continuous infusion of picomolar levels of LPS (or artificial CSF as control) into their fourth ventricle for either 3 or 8 weeks. Longer duration of exposure to LPS infusion further increased the elevated levels of IL-1- $\alpha$, IL-2, IL-4, IL-5, IL-6, IL-12, IL-13, and GM-CSF. This study provides evidence of the influence of chronicity of infection on neuroinflammatory responses in certain brain regions, such as locus coeruleus, that undergo significant cell loss in the early stages of AD (Grudzien et al. 2007). However, the study did not investigate the role of duration of exposure to LPS on cognitive behavior.

In a study of Zhu et al. (2014), the results demonstrated that 7 days of LPS administration significantly increased the latency to the platform and decreased the proportion of time spent in the target quadrant during Morris water maze test, compared to 3 days of LPS administration. Increased expression of $\mathrm{A} \beta$ in the hippocampus was observed following administration of LPS for 7 days, but not for 3 days, indicating that the increased expression of $A \beta$ may be a major factor in the pathogenesis of cognitive dysfunction.

\section{Age of animal during LPS exposure}

Age appears to be an important factor influencing the behavioral responses to LPS. Prenatal (Bakos et al. 2004) and early postnatal (Fan et al. 2005, Pang et al. 2006) LPS exposure has been shown to induce poor neurobehavioral performance and is frequently used to model diseases such as schizophrenia and autism (Powell 2010, Meyer 2014, Waterhouse et al. 2016).

Younger animals seem to be affected to a lesser degree, at a slower pace and do not show speed decrement on day one as shown by the year-old mice (Sparkman et al. 2005). Bardou and colleagues (2014) investigated the age of exposed rats on the neuroinflammatory response to LPS. Male rats at three age groups of young ( 3 months), middle-aged ( 9 months), and aged (23 months) received continuous infusion of picomolar levels of LPS (or artificial CSF as control) into their fourth ventricle. Among all cytokines, TNF- $\alpha$ increase in response to LPS infusion was similar in the different age groups. However, in contrast to young rats, IL-1 $\beta$ did not significantly increase after 3 weeks of infusion in middle-aged and aged rats. Instead, aged rats had significantly increased IFN- $\gamma$ compared to younger rats. However, in another study LPS administration in aged rats induced prolonged neuroinflammation and astrogliosis in the hippocampus (dentate gyrus) with higher mRNA expression and protein levels of TNF- $\alpha$ and IL-1 $\beta$ (Fu et al. 2014).

Age is also an important factor to develop tolerance-like phenomenon (Habicht 1985). Splenic lymphocytes of 12-month and 24-month-old animals are less likely to develop tolerance following repeated endotoxin exposure when compared to splenic lymphocytes obtained from young animals. Thus, old animals exposed to long-term LPS seem to be an ideal model of AD.

\section{Gender}

Almost all rat studies of LPS-induced cognitive impairment model used male rats. However, studies in mice demonstrated a heightened HPA response to LPS in females (Frederic et al. 1993, Spinedi et al. 1997), which may have important behavioral implications.

\section{Conclusion}

Extra caution is needed before extrapolating preclinical findings using LPS to clinical situations. Sensitivity to LPS and the consequent production of proinflammatory cytokines is much greater in humans compared to rodents (Warren et al. 2010). Thus, the doses of LPS given in most rodent models are about $10^{3}-10^{4}$ times the dose required to induce severe disease in humans (Sauter et al. 1980, Taveira et al. 1993). Other factors such as route of administration, nature and duration of exposure as well as age and gender of animal used should be taken into account when designing a study using LPS-induced memory impairment as model for $\mathrm{AD}$.

\section{Conflict of Interest}

There is no conflict of interest.

\section{Acknowledgements}

The authors wish to acknowledge funding from Fundamental Research Grant Scheme (FRGS) (203/PPSP/6171174). 


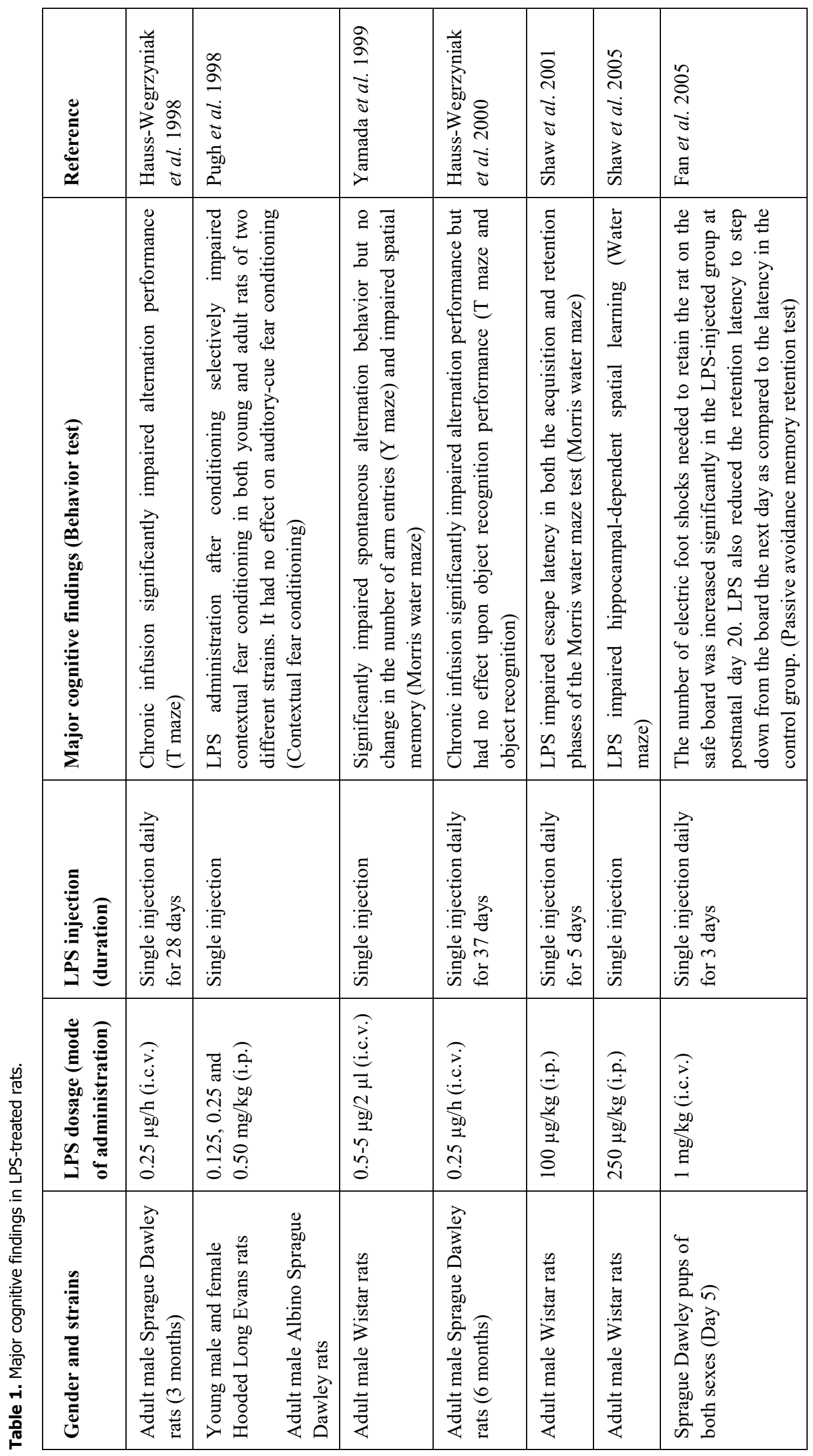




\begin{tabular}{|c|c|c|c|c|c|c|c|c|c|c|}
\hline 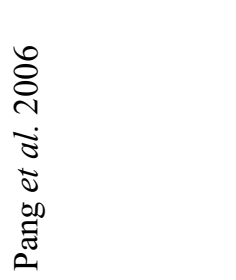 & 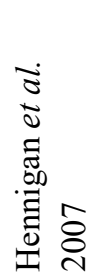 &  & 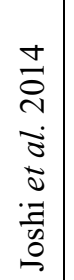 & 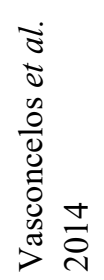 & 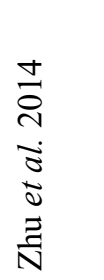 & 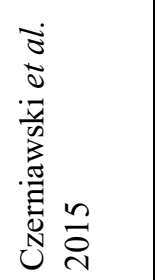 & 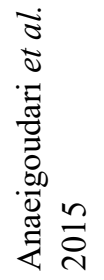 & 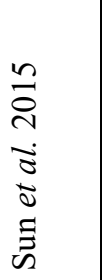 &  & 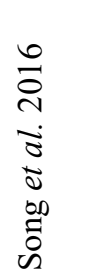 \\
\hline  & 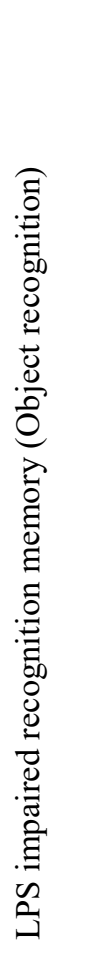 & 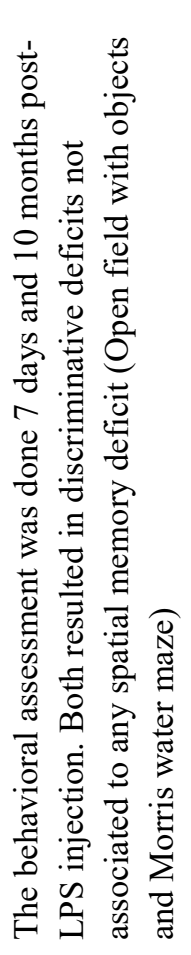 & 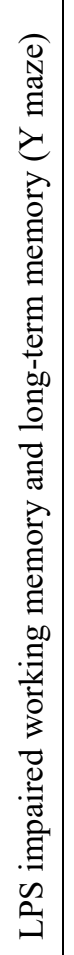 &  & 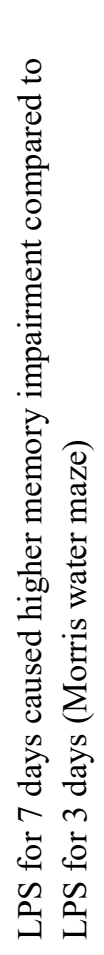 & 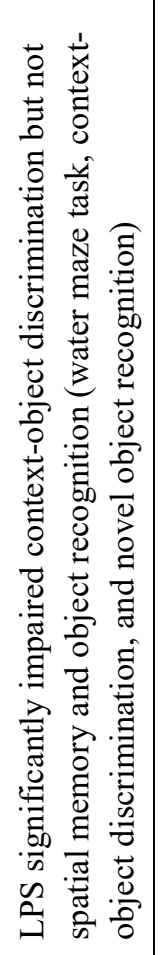 & 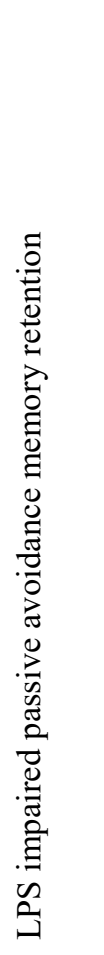 & 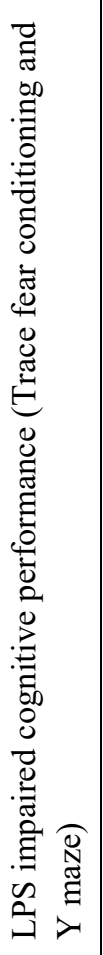 & 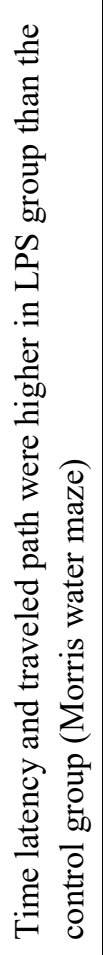 &  \\
\hline 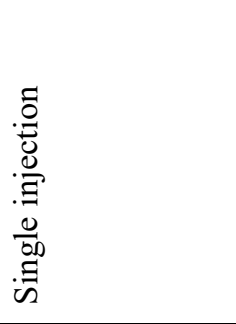 & 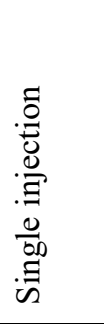 & 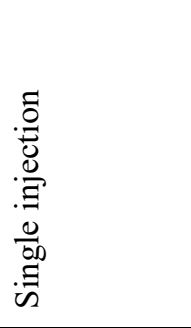 &  & 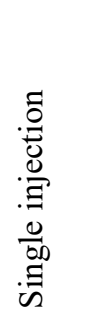 & 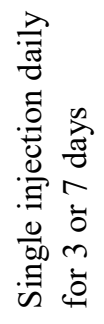 & 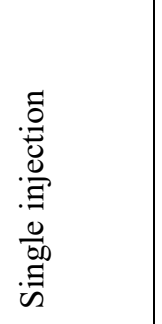 & 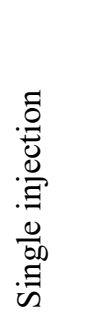 & 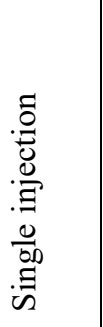 & 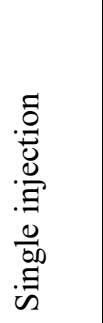 & 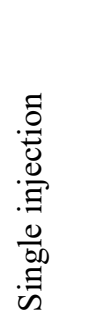 \\
\hline 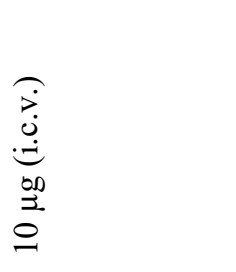 & $\begin{array}{l}\stackrel{\overbrace{}}{0} \\
\dot{0} \\
00 \\
000 \\
0 \\
0 \\
0 \\
0\end{array}$ & 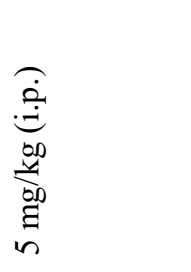 & 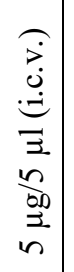 & 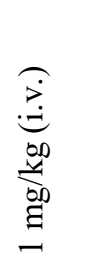 & 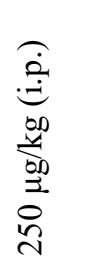 & 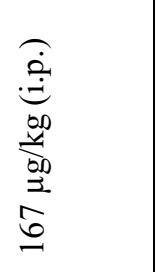 & 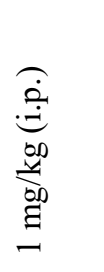 & 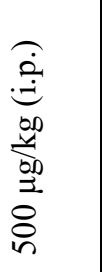 & 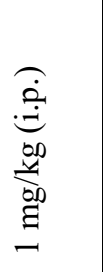 & 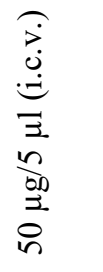 \\
\hline 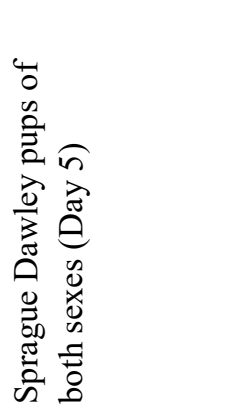 & 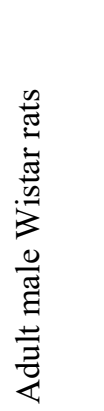 & 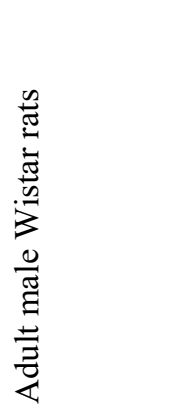 &  & 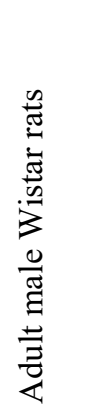 & 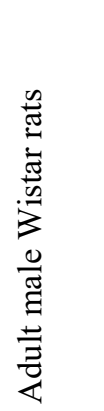 & 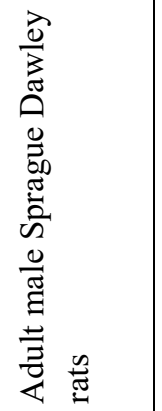 & 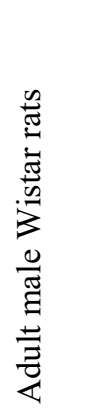 & 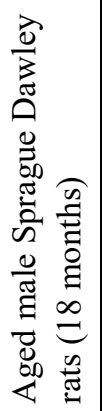 & 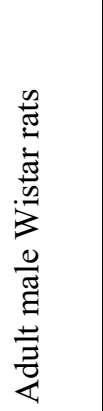 & 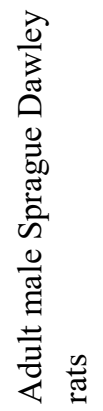 \\
\hline
\end{tabular}




\section{References}

ALZHEIMER'S DISEASE INTERNATIONAL: World Alzheimer Report. 2009.

ANAEIGOUDARI A, SHAFEI MN, SOUKHTANLOO M, SADEGHNIA HR, REISI P, BEHESHTI F, MOHEBBATI R, MOUSAVI SM, HOSSEINI M: Lipopolysaccharide-induced memory impairment in rats is preventable using 7-nitroindazole. Arq Neuropsiquiatr 73: 784-790, 2015.

ANAEIGOUDARI A, SOUKHTANLOO M, REISI P, BEHESHTI F, HOSSEINI M: Inducible nitric oxide inhibitor aminoguanidine, ameliorates deleterious effects of lipopolysaccharide on memory and long term potentiation in rat. Life Sci 158: 22-30, 2016.

BAKOS J, DUNCKO R, MAKATSORI A, PIRNIK Z, KISS A, JEZOVA D: Prenatal immune challenge affects growth, behavior, and brain dopamine in offspring. Ann N Y Acad Sci 1018: 281-287, 2004.

BARDOU I, KAERCHER RM, BROTHERS HM, HOPP SC, ROYER S, WENK GL: Age and duration of inflammatory environment differentially affect then neuroimmune response and catecholaminergic neurons in the midbrain and brainstem. Neurobiol Aging 35: 1065-1073, 2014.

BIVALACQUA TJ, SUSSAN TE, GEBSKA MA, STRONG TD, BERKOWITZ DE, BISWAL S, BURNETT AL, CHAMPION HC: Sildenafil inhibits superoxide formation and prevents endothelial dysfunction in a mouse model of secondhand smoke induced erectile dysfunction. J Urol 181: 899-906, 2009.

BLASKO I, MARX F, STEINER E, HARTMANN T, GRUBECK-LOEBENSTEIN B: TNFalpha plus IFNgamma induce the production of Alzheimer beta-amyloid peptides and decrease the secretion of APPs. FASEB J 13: 63-68, 1999.

BLATTEIS CM: Role of OVLT in the febrile responses to circulating pyrogens. Prog Brain Res 91: 409-412, 1992.

BLOCK ML, HONG JS: Microglia and inflammation-mediated neurodegeneration: Multiple triggers with a common mechanism. Prog Neurobiol 76: 77-98, 2005.

BOSSÙ P, CUTULI D, PALLADINO I, CAPORALI P, ANGELUCCI F, LARICCHIUTA D, GELFO F, DE BARTOLO P, CALTAGIRONE C, PETROSINI L: A single intraperitoneal injection of endotoxin in rats induces long-lasting modifications in behavior and brain protein levels of TNF- $\alpha$ and IL-18. J Neuroinflam 9: $101,2012$.

BURTON MD, JOHNSON RW: Interleukin-6 trans-signaling in the senescent mouse brain is involved in infectionrelated deficits in contextual fear conditioning. Brain Behav Immun 26: 732-738, 2012.

BUXBAUM JD, OISHI M, CHEN HI, PINKAS-KRAMARSKI R, JAFFE EA, GANDY SE, GREENGARD P: Cholinergic agonists and interleukin 1 regulate processing and secretion of the Alzheimer beta/A4 amyloid protein precursor. Proc Natl Acad Sci U S A 89: 10075-10078, 1992.

CANDIRACCI M, PIATTI E, DOMINGUEZ-BARRAGÁN M, GARCÍA-ANTRÁS D, MORGADO B, RUANO D, GUTIÉRREZ JF, PARRADO J, CASTAÑO A: Anti-inflammatory activity of a honey flavonoid extract on lipopolysaccharide-activated N13 microglial cells. J Agric Food Chem 60: 12304-12311, 2012.

CAVANAUGH SE, PIPPIN JJ, BARNARD ND: Animal models of Alzheimer disease: historical pitfalls and a path forward. ALTEX 1: 279-302, 2014.

CHAI CK: The genetics of Alzheimer's disease. Am J Alzheimers Dis Other Demen 22: 37-41, 2007.

CHARTIER-HARLIN MC, CRAWFORD F, HOULDEN H, WARREN A, HUGHES D, FIDANI L, GOATE A, ROSSOR M, ROQUES P, HARDY J, MULLAN M: Early-onset Alzheimer's disease caused by mutations at codon 717 of the beta-amyloid precursor protein gene. Nature 353: 844-846, 1991.

CHUI DH, TANAHASHI H, OZAWA K, IKEDA S, CHECLER F, UEDA O, SUZUKI H, ARAKI W, INOUE H, SHIROTANI K, TAKAHASHI K, GALLYAS F, TABIRA T: Transgenic mice with Alzheimer presenilin 1 mutations show accelerated neurodegeneration without amyloid plaque formation. Nat Med 5: 560-564, 1999.

CORDER EH, SAUNDERS AM, STRITTMATTER WJ, SCHMECHEL DE, GASKELL PC, SMALL GW, ROSES AD, HAINES JL, PERICAK-VANCE MA: Gene dose of apolipoprotein E type 4 allele and the risk of Alzheimer's disease in late onset families. Science 261: 921-923, 1993.

CZERNIAWSKI J, MIYASHITA T, LEWANDOWSKI G, GUZOWSKI JF: Systemic lipopolysaccharide administration impairs retrieval of context-object discrimination, but not spatial, memory: evidence for selective disruption of specific hippocampus-dependent memory functions during acute neuroinflammation. Brain Behav Immun 44: 159-166, 2015. 
DAULATZAI MA: Fundamental role of pan-inflammation and oxidative-nitrosative pathways in neuropathogenesis of Alzheimer's disease. Am J Neurodegener Dis 5: 1-28, 2016.

DE VUGT ME, STEVENS F, AALTEN P, LOUSBERG R, JASPERS N, VERHEY FR: A prospective study of the effects of behavioral symptoms on the institutionalization of patients with dementia. Int Psychogeriatr 17: 577-589, 2005.

ELMQUIST JK, SCAMMELL TE, SAPER CB: Mechanisms of CNS response to systemic immune challenge: the febrile response. Trends Neurosci 20: 565-570, 1997.

ERICKSON MA, HARTVIGSON PE, MOROFUJI Y, OWEN JB, BUTTERFIELD DA, BANKS WA: Lipopolysaccharide impairs amyloid $\beta$ efflux from brain: altered vascular sequestration, cerebrospinal fluid reabsorption, peripheral clearance and transporter function at the blood-brain barrier. J Neuroinflam 9: 150, 2012.

ERICSSON A, KOVACS KJ, SAWCHENKO PE: A functional anatomical analysis of central pathways subserving the effects of interlukin-1 on stress-related neuroendocrine neurons. J Neurosci 14: 897-913, 1994.

EXLINE MC, CROUSER ED: Mitochondrial mechanisms of sepsis induced organ failure. Front Biosci 13: 5031-5041, 2008.

FAN LW, PANG Y, LIN S, TIEN LT, MA T, RHODES PG, CAI Z: Minocycline reduces lipopolysaccharide-induced neurological dysfunction and brain injury in the neonatal rat. $J$ Neurosci Res 82: 71-82, 2005.

FERRI CP, AMES D, PRINCE M, 10/66 DEMENTIA RESEARCH GROUP: Behavioral and psychological symptoms of dementia in developing countries. Int Psychogeriatr 16: 441-459, 2004.

FITZPATRICK AL, KULLER LH, LOPEZ OL, KAWAS CH, JAGUST W: Survival following dementia onset: Alzheimer's disease and vascular dementia. J Neurol Sci 229-230: 43-49, 2005.

FREDERIC F, OLIVER C, WOLLMAN E, DELHAYE-BOUCHARD N, MARIANI J: IL-1 and LPS induce a sexually dimorphic response of the hypothalamo pituitary-adrenal axis in several mouse strains. Eur Cytokine Netw 4: 321-329, 1993.

FU HQ, YANG T, XIAO W, FAN L, WU Y, TERRANDO N, WANG TL: Prolonged neuroinflammation after lipopolysaccharide exposure in aged rats. PLoS One 9: e106331, 2014.

GALLEY HF: Oxidative stress and mitochondrial dysfunction in sepsis. Br J Anaesth 107: 57-64, 2011.

GANGULI M, DODGE HH, SHEN C, PANDAV RS, DEKOSKY ST: Alzheimer disease and mortality: a 15-year epidemiological study. Arch Neurol 62: 779-784, 2005.

GAO HM, JIANG J, WILSON B, ZHANG W, HONG JS, LIU B: Microglial activation's mediated delayed and progressive degeneration of rat nigral dopaminergic neurons: relevance to Parkinson's disease. $J$ Neurochem 81: 1285-1297, 2002.

GATZ M, REYNOLDS CA, FRATIGLIONI L, JOHANSSON B, MORTIMER JA, BERG S, FISKE A, PEDERSEN NL: Role of genes and environments for explaining Alzheimer disease. Arch Gen Psychiatry 3: 168-174, 2006.

GHOSH S, LERTWATTANARAK R, GARDUÑO JDE J, GALEANA JJ, LI J, ZAMARRIPA F, LANCASTER JL, MOHAN S, HUSSEY S, MUSI N: Elevated muscle TLR4 expression and metabolic endotoxemia in human aging. J Gerontol A Biol Sci Med Sc 70: 232-246, 2015.

GOATE A, CHARTIER-HARLIN MC, MULLAN M, BROWN J, CRAWFORD F, FIDANI L, GIUFFRA L, HAYNES A, IRVING N, JAMES L, MANT R, NEWTON P, ROOKE K, ROQUES P, TALBOT C, PERICAK-VANCE M, ROSES A, WILLIAMSON R, ROSSOR M, OWEN M, HARDY J: Segregation of a missense mutation in the amyloid precursor protein gene with familial Alzheimer's disease. Nature 349: 704-706, 1991.

GOURAS GK, TSAI J, NASLUND J, VINCENT B, EDGAR M, CHECLER F, GREENFIELD JP, HAROUTUNIAN V, BUXBAUM JD, XU H, GREENGARD P, RELKIN NR: Intraneuronal A $\beta 42$ accumulation in human brain. Am J Pathol 156: 15-20, 2000.

GRUDZIEN A, SHAW P, WEINTRAUB S, BIGIO E, MASH DC, MESULAM MM: Locus coeruleus neurofibrillary degeneration in aging, mild cognitive impairment and early Alzheimer's disease. Neurobiol Aging 28: 327-335, 2007.

HABICHT GS: Body temperature in normal and endotoxin-treated mice of different ages. Mech Ageing Dev 16: 97-104, 1981. 
HABICHT GS: Acquired immunological tolerance in aged mice II. The cellular basis of the loss of tolerance sensitivity. Mech Ageing Dev 30: 23-36, 1985.

HAILMAN E, LICHENSTEIN HS, WURFEL MM, MILLER DS, JOHNSON DA, KELLEY M, BUSSE LA, ZUKOWSKI MM, WRIGHT SD: Lipopolysaccharide (LPS)-binding protein accelerates the binding of LPS to CD14. J Exp Med 179: 269-277, 1994.

HANSEN MK, NGUYEN KT, FLESHNER M, GOEHLER LE, GAYKEMA RP, MAIER SF, WATKINS LR: Effects of vagotomy on serum endotoxin, cytokines and corticosterone after intraperitoneal lipopolysaccharide. $A m J$ Physiol Regul Integr Comp Physiol 278: R331-R336, 2000.

HARDY J, SELKOE DJ: The amyloid hypothesis of Alzheimer's disease: progress and problems on the road to therapeutics. Science 297: 353-356, 2002.

HART BL: Biological basis of the behavior of sick animals. Neurosci Biobehav Rev 12: 123-137, 1988.

HAUSS-WEGRZYNIAK B, DOBRZANSKI P, STOEHR JD, WENK GL: Chronic neuroinflammation in rats reproduces components of the neurobiology of Alzheimer's disease. Brain Res 780: 294-303, 1998.

HAUSS-WEGRZYNIAK B, VANNUCCHI MG, WENK GL: Behavioral and ultrastructural changes induced by chronic neuroinflammation in young rats. Brain Res 859: 157-166, 2000.

HENNIGAN A, TROTTER C, KELLY AM: Lipopolysaccharide impairs long-term potentiation and recognition memory and increases p75NTR expression in the rat dentate gyrus. Brain Res 1130: 158-166, 2007.

HIROSE Y, IMAI Y, NAKAJIMA K, TAKEMOTO N, TOYA S, KOHSAKA S: Glial conditioned medium alters the expression of amyloid precursor protein in SH-SY5Y neuroblastoma cells. Biochem Biophys Res Commun 198: 504-509, 1994.

HOOZEMANS JJ, ROZEMULLER AJ, JANSSEN I, DE GROOT CJ, VEERHUIS R, EIKELENBOOM P: Cyclooxygenase expression in microglia and neurons in Alzheimer's disease and control brain. Acta Neuropathol (Berl) 101: 2-8, 2001.

HOUDEK HM, LARSON J, WATT JA, ROSENBERGER TA: Bacterial lipopolysaccharide induces a dose-dependent activation of neuroglia and loss of basal forebrain cholinergic cells in the rat brain. Inflamm Cell Signal 1: e47, 2014.

IQBAL K, GRUNDKE-IQBAL I: Discoveries of tau, abnormally hyperphosphorylated tau and others of neurofibrillary degeneration: a personal historical perspective. JAD 9: 219-242, 2006.

IRVINE GB, EL-AGNAF OM, SHANKAR GM, WALSH DM: Protein aggregation in the brain: the molecular basis for Alzheimer's and Parkinson's diseases. Mol Med 14: 451-464, 2008.

JAEGER LB, DOHGU S, SULTANA R, LYNCH JL, OWEN JB, ERICKSON MA, SHAH GN, PRICE TO, FLEEGAL-DEMOTTA MA, BUTTERFIELD DA, BANKS WA: Lipopolysaccharide alters the blood-brain barrier transport of amyloid beta protein: a mechanism for inflammation in the progression of Alzheimer's disease. Brain Behav Immun 23: 507-517, 2009.

JANG JH, SURH YJ: Beta-amyloid-induced apoptosis is associated with cyclooxygenase-2 up-regulation via the mitogen-activated protein kinase-NF-kappaB signaling pathway. Free Radic Biol Med 38: 1604-1613, 2005.

JOSHI R, GARABADU D, TEJA GR, KRISHNAMURTHY S: Silibinin ameliorates LPS-induced memory deficits in experimental animals. Neurobiol Learn Mem 116: 117-131, 2014.

KENT S, BLUTHE R-M, KELLEY KW, DANTZER R: Sickness behaviour as a new target for drug development. Trends Pharmacol Sci 13: 24-28, 1992.

KLEIN SL, NELSON RJ: Activation of the immune-endocrine system with lipopolysaccharide reduces affiliative behaviours involves. Behav Neurosci 113: 1042-1048, 1999.

KOBAYASHI K, HERNANDEZ LD, GALAN JE, JANEWAY CA JR, MEDZHITOV R, FLAVELL RA: IRAK-M is a negative regulator of Toll-like receptor signaling. Cell 110: 191-202, 2002.

LECANU L, PAPADOPOULOS V: Modelling Alzheimer's disease with non-transgenic rat models. Alzheimers Res Ther 5: 17, 2013.

LEE JW, LEE YK, YUK DY, CHOI DY, BAN SB, OH KW, HONG JT: Neuro-inflammation induced by lipopolysaccharide causes cognitive impairment through enhancement of beta-amyloid generation. J Neuroinflam 5: 37, 2008. 
LEHNARDT S, MASSILLON L, FOLLETT P, JENSEN FE, RATAN R, ROSENBERG PA, VOLPE JJ, VARTANIAN T: Activation of innate immunity in the CNS triggers neurodegeneration through a toll-like receptor 4-dependent pathway. Proc Natl Acad Sci U S A 100: 8514-8519, 2003.

LEVY-LAHAD E, WASCO W, POORKAJ P, ROMANO DM, OSHIMA J, PETTINGELL WH, YU C, JONDRO PD, SCHMIDT SD, WANG K, CROWLEY AC, FU Y-H, GUENETTE SY, GALAS D, NEMENS E, WIJSMAN EM, BIRD TD, SCHELlENBERG GD, TANZI RE: Candidate gene for the chromosome 1 familial Alzheimer's disease locus. Science 269: 973-977, 1995.

LOWES DA, WEBSTER NR, MURPHY MP, GALLEY HF: Antioxidants that protect mitochondria reduce interleukin-6 and oxidative stress, improve mitochondrial function, and reduce biochemical markers of organ dysfunction in a rat model of acute sepsis. B J Anaesth 110: 472-480, 2013.

MAITRA U, DENG H, GLAROS T, BAKER B, CAPELLUTO DG, LI Z, LI L: Molecular mechanisms responsible for the selective and low-grade induction of proinflammatory mediators in murine macrophages by lipopolysaccharide. J Immunol 189: 1014-1023, 2012.

MEYER U: Prenatal poly (I:C) exposure and other developmental immune activation models in rodent systems. Biol Psychiatry 75: 307-315, 2014.

MIKLOSSY J: Chronic inflammation and amyloidogenesis in Alzheimer's disease - role of spirochetes. JAD 13: 381-391, 2008.

MIZUNO T, SAWADA M, MARUNOUCHI T, SUZUMURA A: Production of interleukin-10 by mouse glial cells in culture. Biochem Biophys Res Commun 205: 1907-1915, 1994.

MULLAN M, CRAWFORD F, AXELMAN K, HOULDEN H, LILIUS L, WINBLAD B, LANNFELT L: A pathogenic mutation for probable Alzheimer's disease in the APP gene at the N-terminus of beta-amyloid. Nat Genet 1: 345-347, 1992.

NGUYEN KT, DEAK T, OWENS SM, KOHNO T, FLESHNER M, WATKINS LR, MAIER SF: Exposure to acute stress induces brain interleukin-1 beta protein in the rat. J Neurosci 18: 2239-2246, 1998.

OBERMEYER TS, YONICK D, LAUING K, STOCK SR, NAUER R, STROTMAN P, SHANKAR R, GAMELLI R, STOVER M, CALLACI JJ: Mesenchymal stem cells facilitate fracture repair in an alcohol-induced impaired healing model. J Orthop Trauma 26: 712-718, 2012.

OHANIAN SH, SCHWAB JH: Persistence of group a streptococcal cell walls related to chronic inflammation of rabbit dermal connective tissue. J Exp Med 125: 1137-1148, 1967.

OITZL MS, VAN OERS H, SCHOBITZ B, DE KLOET WR: Interlukin-1 beta, but not interlukin-6, impairs spatial navigation learning. Brain Res 613: 160-163, 1993.

PANG Y, FAN LW, ZHENG B, CAI Z, RHODES PG: Role of interleukin-6 in lipopolysaccharide-induced brain injury and behavioral dysfunction in neonatal rats. Neuroscience 141: 745-755, 2006.

PARIS D, TOWNSEND KP, OBREGON DF, HUMPHREY J, MULLAN M: Pro-inflammatory effect of freshly solubilized beta-amyloid peptides in the brain. Prostaglandins Other Lipid Mediat 70: 1-12, 2002.

PASINETTI GM: Cyclooxygenase and Alzheimer's disease: implications for preventive initiatives to slow the progression of clinical dementia. Arch Gerontol Geriatr 33: 13-28, 2001.

PASINETTI GM: From epidemiology to therapeutic trials with antiinflammatory drugs in Alzheimer's disease: the role of NSAIDs and cyclooxygenase in beta-amyloidosis and clinical dementia. JAD 4: 435-445, 2002.

PASINETTI GM, AISEN PS: Cyclooxygenase-2 expression is increased in frontal cortex of Alzheimer's disease brain. Neuroscience 87: 319-324, 1998.

PETRASEK T, SKURLOVA M, MALENINSKA K, VOJTECHOVA I, KRISTOFIKOVA Z, MATUSKOVA H, SIROVA J, VALES K, RIPOVA D, STUCHLIK A: A rat model of Alzheimer's disease based on abeta42 and pro-oxidative substances exhibits cognitive deficit and alterations in glutamatergic and cholinergic neurotransmitter systems. Front Aging Neurosci 8: 83, 2016.

POWELL SB: Models of neurodevelopmental abnormalities in schizophrenia. Curr Top Behav Neurosci 4: 435-481, 2010.

PUGH CR, KUMAGAWA K, FLESHNER M, WATKINS LR, MAIER SF, RUDY JW: Selective effects of peripheral lipopolysaccharide administration on contextual and auditory-cue fear conditioning. Brain Behav Immun 12: 212-229, 1998. 
RIVEST S: Regulation of innate immune responses in the brain. Nat Rev Immunol 9: 429-439, 2009.

ROSSOR MN, FOX NC, FREEBOROUGH PA: Clinical features of sporadic and familial Alzheimer's disease. Neurodegeneration 5: 393-397, 1996.

SADIGH-ETEGHAD S, TALEBI M, FARHOUDI M: Association of apolipoprotein E epsilon 4 allele with sporadic late onset Alzheimer's disease. A meta-analysis. Neurosciences (Riyadh) 17: 321-326, 2012.

SASTRE M, DEWACHTER I, LANDRETH GE, WILLSON TM, KLOCKGETHER T, VAN LEUVEN F, HENEKA MT: Nonsteroidal anti-inflammatory drugs and peroxisome proliferator-activated receptor-gamma agonists modulate immunostimulated processing of amyloid precursor protein through regulation of beta-secretase. J Neurosci 23: 9796-9804, 2003.

SAUTER C, WOLFENSBERGER C: Interferon in human serum after injection of endotoxin. Lancet 2: 852-853, 1980. SCHELLENBERG GD, BIRD TD, WIJSMAN EM, ORR HT, ANDERSON L, NEMENS E, WHITE JA, BONNYCASTLE L, WEBER JL, ALONSO ME, POTTER H, HESTON LL, MARTIN GM: Genetic linkage evidence for a familial Alzheimer's disease locus on chromosome 14. Science 258: 668-671, 1992.

SCHMID CD, MELCHIOR B, MASEK K, PUNTAMBEKAR SS, DANIELSON PE, LO DD, SUTCLIFFE JG, CARSON MJ: Differential gene expression in LPS/IFNgamma activated microglia and macrophages: in vitro versus in vivo. $J$ Neurochem 109: 117-125, 2009.

SHAW KN, COMMINS ST, O’MARA SM: Lipopolysaccharide causes deficits in spatial learning in the water maze but not in BDNF expression in the rat dentate gyrus. Behav Brain Res 124: 47-54, 2001.

SHAW KN, COMMINS ST, O’MARA SM: Cyclooxygenase inhibition attenuates endotoxin-induced spatial learning deficits, but not an endotoxin-induced blockade of long-term potentiation. Brain Res 1038: 231-237, 2005.

SHENG JG, BORA SH, XU G, BORCHELT DR, PRICE DL, KOLIATSOS VE: Lipopolysaccharide inducedneuroinflammation increases intracellular accumulation of amyloid precursor protein and amyloid beta peptide in APPswe transgenic mice. Neurobiol Dis 14: 133-145, 2003.

SHERRINGTON R, ROGAEV EI, LIANG Y, ROGAEVA EA, LEVESQUE G, IKEDA M, CHI H, LIN C, LI G, HOLMAN K, TSUDA T, MAR L, FONCIN JF, BRUNI AC, MONTESI MP, SORBI S, RAINERO I, PINESSI L, NEE L, CHUMAKOV I, POLLEN D, BROOKES A, SANSEAU P, POLINSKY RJ, WASCO W, DA SILVA HA, HAINES JL, PERKICAK-VANCE MA, TANZI RE, ROSES AD, FRASER PE, ROMMENS JM, ST GEORGE-HYSLOP PH: Cloning of a gene bearing missense mutations in early-onset familial Alzheimer's disease Nature 375: 754-760, 1995.

SONG X, ZHOU B, ZHANG P, LEI D, WANG Y, YAO G, HAYASHI T, XIA M, TASHIRO S, ONODERA S, IKEJIMA T: Protective effect of silibinin on learning and memory impairment in LPS-treated rats via ROSBDNF-TrkB pathway. Neurochem Res 41: 1662-1672, 2016.

SPARKMAN NL, MARTIN LA, CALVERT WS, BOEHM GW: Effects of intraperitoneal lipopolysaccharide on Morris maze performance in year-old and 2-month-old female C57BL/6J mice. Behav Brain Res 159: 145-151, 2005.

SPINEDI E, CHISARI A, PRALONG F, GAILLARD RC: Sexual dimorphism in the mouse hypothalamic-pituitaryadrenal axis function after endotoxin and insulin stresses during development. Neuroimmunomodulation 4: 77-83, 1997.

STRITTMATTER WJ, SAUNDERS AM, SCHMECHEL D, PERICAK-VANCE M, ENGHILD J, SALVESEN GS, ROSES AD: Apolipoprotein E: High-avidity binding to beta-amyloid and increased frequency of type 4 allele in late-onset familial Alzheimer disease. Proc Natl Acad Sci U S A 90: 1977-1981, 1993.

SUN J, ZHANG S, ZHANG X, ZHANG X, DONG H, QIAN Y: IL-17A is implicated in lipopolysaccharide-induced neuroinflammation and cognitive impairment in aged rats via microglial activation. $J$ Neuroinflam 12: 165 , 2015.

SZABADOS T, DUL C, MAJTÉNYI K, HARGITAI J, PÉNZES Z, URBANICS R: A chronic Alzheimer's model evoked by mitochondrial poison sodium azide for pharmacological investigations. Behav Brain Res 154: 31-40, 2004.

TAKEMURA T, MAKINO S, TAKAO T, ASABA K, SUEMARU S, HASHIMOTO K: Hypothalamic-pituitaryadrenocortical responses to single vs. repeated endotoxin lipopolysaccharide administration in the rat. Brain Res 767: 181-191, 1997. 
TANSEY MG, MCCOY MK, FRANK-CANNON TC: Neuroinflammatory mechanisms in Parkinson's disease: Potential environmental triggers, pathways, and targets for early therapeutic intervention. Exp Neurol 208: $1-25,2007$.

TAVEIRA DA SILVA AM, KAULBACH HC, CHUIDIAN FS, LAMBERT DR, SUFFREDINI AF, DANNER RL: Brief report: shock and multiple-organ dysfunction after self-administration of Salmonella endotoxin. $N$ Engl $J$ Med 328: 1457-1460, 1993.

VASCONCELOS AR, YSHII LM, VIEL TA, BUCK HS, MATTSON MP, SCAVONE C, KAWAMOTO EM: Intermittent fasting attenuates lipopolysaccharide-induced neuroinflammation and memory impairment. J Neuroinflam 11: 85, 2014.

VASSAR R: The beta-secretase, BACE: a prime drug target for Alzheimer's disease. J Mol Neurosci 17: 157-170, 2001.

VÍCTOR VM, ESPULGUES JV, HERNÁNDEZ-MIJARES A, ROCHA M: Oxidative stress and mitochondrial dysfunction in sepsis: a potential therapy with mitochondria-targeted antioxidants. Infect Disord Drug Targets 9: 376-389, 2009.

WALTER J, KAETHER C, STEINER H, HAASS C: The cell biology of Alzheimer's disease: uncovering the secrets of secretases. Curr Opin Neurobiol 11: 585-590, 2001.

WALTER S, DOERING A, LETIEMBRE M, LIU Y, HAO W, DIEM R, BERNREUTHER C, GLATZEL M, ENGELHARDT B, FASSBENDER K: The LPS receptor, CD14 in experimental autoimmune encephalomyelitis and multiple sclerosis. Cell Physiol Biochem 17: 167-172, 2006.

WARREN HS, FITTING C, HOFF E, ADIB-CONQUY M, BEASLEY-TOPLIFFE L, TESINI B, LIANG X, VALENTINE C, HELLMAN J, HAYDEN D, CAVAILLON JM: Resilience to bacterial infection: difference between species could be due to proteins in serum. J Infect Dis 201: 223-232, 2010.

WATERHOUSE U, ROPER VE, BRENNAN KA, ELLENBROEK BA: Nicotine ameliorates schizophrenia-like cognitive deficits induced by maternal LPS exposure: a study in rats. Dis Model Mech 9: 1159-1167, 2016.

WELSER-ALVES JV, MILNER R: Microglia are the major source of TNF- $\alpha$ and TGF- $\beta 1$ in postnatal glial cultures; regulation by cytokines, lipopolysaccharide, and vitronectin. Neurochem Int 63: 47-53, 2013.

WHITTON PS: Inflammation as a causative factor in the aetiology of Parkinson's disease. Brit J Pharmacol 150: 963-976, 2007.

WILKINS RH, BRODY IA: Alzheimer's disease. Arch Neurol 21: 109-110, 1969.

WIRTHS O, MULTHAUP G, CZECH C, BLANCHARD V, MOUSSAOUI S, TREMP G, PRADIER L, BEYREUTHER K, BAYER TA: Intraneuronal Abeta accumulation precedes plaque formation in betaamyloid precursor protein and presenilin-1 double-transgenic mice. Neurosci Lett 306: 116-120, 2001.

YAMADA K, KOMORI Y, TANAKA T, SENZAKI K, NIKAI T, SUGIHARA H, KAMEYAMA T, NABESHIMA T: Brain dysfunction associated with an induction of nitric oxide synthase following an intracerebral injection of lipopolysaccharide in rats. Neuroscience 88: 281-294, 1999.

YASUDA N, GREER MA: Evidence that the hypothalamus mediates endotoxin stimulation of adrenocorticotrophic hormone secretion. Endocrinology 102: 947-953, 1978.

ZHANG Y-H, LU J, ELMQUIST JK, SAPER CB: Lipopolysaccharide activates specific populations of hypothalamic and brainstem neurons that project to the spinal cord. J Neurosci 20: 6578-6586, 2000.

ZHAO W, XIE W, LE W, BEERS DR, HE Y, HENKEL JS, SIMPSON EP, YEN AA, XIAO Q, APPEL SH: Activated microglia initiate motor neuron injury by a nitric oxide and glutamate-mediated mechanism. $J$ Neuropathol Exp Neurol 63: 964-977, 2004.

ZHU B, WANG ZG, DING J, LIU N, WANG DM, DING LC, YANG C: Chronic lipopolysaccharide exposure induces cognitive dysfunction without affecting BDNF expression in the rat hippocampus. Exp Ther Med 7: 750-754, 2014. 